\title{
Analisis Penerapan Higher Order Thinking Skills (HOTS) pada Pembelajaran Biologi di Sman 2 Baubau
}

\author{
1Fahmil Ikhsan Taharu, ${ }^{1}$ Samritin, ${ }^{1}$ Nurwahida, ${ }^{1}$ Kusrini, \\ ${ }^{2}$ Arwan Bin Laeto
}

Email: fahmilikhsanbiologik3@gmail.com

\begin{abstract}
Abstrak
Penerapan Higher Order Thinking Skills (HOTS) pada pembelajaran biologi menjadi fokus dari kurikulum. Hal ini menyaratkan agar setiap sekolah termasuk SMAN 2 Baubau untuk mengintegrasikan HOTS pada pembelajaran biologi. Penelitian ini bertujuan untuk mendeskripsikan proses penerapan HOTS pada pembelajaran biologi di SMAN 2 Baubau. Penelitian ini merupakan penelitian deskriptif kualitatifinstrumen yang digunakan dalam penelitian ini adalah pedoman wawancara, lembar observasi dan angket respon siswa terhadap pembelajaran. Analisis data dalam penelitian ini merupakan analisis data kualitatif yang terdiri atas tahapan pengumpulan data, reduksi data, penyajian data, dan penarikan kesimpulan. Berdasarkan hasil penelitian diperoleh bahwa (1) Penerapan HOTS pada pembelajaran biologi di SMAN 2 Baubau dilakukan melalu proses pembelajaran intrakurikuler dengan dilaksanakan pada tahap perencanaan, pelaksanaan dan evaluasi, serta tahap tindak lanjut hasil pembelajaran, dan (2) Penerapan HOTS dilaksanakan melalui scenario pembuatan peta pikiran, kartu flash, praktikum dan praktikum lapangan, proyek lingkungan dan bioteknologi, dokter siswa menjelaskan, pembuatan video penyalahgunaan narkoba, duta ASI dan Keluarga Berencana, Penyusunan artikel, Tutor Sebaya, dan Pembuatan Timeline.
\end{abstract}

Keywords: HOTS; Pembelajaran Biologi; SMAN 2 Baubau

\begin{abstract}
The application of Higher Order Thinking Skills (HOTS) in biology learning be the focus of the curriculum. This presuppose for every school including SMAN 2 Baubau, to integrate HOTS into biology learning. This study aims to describe the application process of HOTS in biology learning at SMAN 2 Baubau. This research is a qualitative descriptive study by using the instruments are interview guidelines, observation sheets and student responses questionnaires towards learning process. Data analysis in this study is a qualitative data analysis consisting of stages are data collection, data reduction, data presentation, and drawing conclusions. Based on the results, the study was found that (1) the application of HOTS in biology learning at SMAN 2 Baubau was conducted through the intra-curricular learning process that carried out on the planning, implementation and evaluation stages, as well as the follow-up stages of learning outcomes, and (2) the application of HOTS was conducted through the scenarios of mind-mapping, flash cards, indoor and outdoor practice, environmental and biotechnology projects, the student doctor,video making of drug abuse, ASI ambassadors and family planning, preparing articles, peer tutoring, and timelines making.
\end{abstract}

Keywords: HOTS; Biology Learning; SMAN 2 Baubau

\footnotetext{
${ }^{1}$ Fakultas Keguruan dan Ilmu Pendidikan, Universitas Muhammadiyah Buton, Indonesia

${ }^{2}$ Program Studi Pendidikan Dokter, Universitas Sriwijaya, Indonesia
} 


\section{PENDAHULUAN}

Pembelajaran di kelas merupakan aktivitas utama dalam proses pendidikan formal pada setiap jenjang pendidikan. Berbagai kompetensi dan pengetahuan diajarkan dan dilatihkan agar peserta didik mampu menguasai tujuan-tujuan belajar yang dimuat dalam kurikulum. Penguasaan konten dan kompetensi yang dimandatkan oleh kurikulum dalam rangka meningkatkan daya saing peserta didik menjadi upaya yang wajib untuk dilaksanakan oleh guru semua mata pelajaran yang diajarkan di sekolah termasuk biologi.

Yusup (2018) menyatakan bahwa guru memiliki kesulitan dalam menyelenggarakan pembelajaran biologi, sedangkan Cimer (2012) melaporkan bahwa materi-materi tertentu pada pelajaran biologi memiliki tingkat kesulitannya sendiri dan siswa memiliki kesulitan untuk mempelajarinya. Peran penting guru biologi sebagai profesional dalam penyelenggaraan pembelajaran menjadi salah satu kunci bagi keberhasilan belajar peserta didik dan lebih jauh dapat mengahasilkan lulusan yang berkualitas.

Guru diharapkan mampu dan kompeten dalam mengembangkan proses pembelajaran yang baik dan efektif sehingga dapat menghasilkan proses pendidikan yang berkualitas yang mampu menghasilkan peserta didik yang berdaya saing tinggi. Salah satu keterampilan yang disyaratkan oleh kurikulum untuk difasilitasi perolehannya melalui proses pembelajaran adalah keterampilan berpikir atau thinking skills. Keterampilan berpikir adalah proses berpikir kompleks dalam menguraikan materi, membuat kesimpulan, membangun representasi, menganalisis, dan membangun hubungan dengan melibatkan aktivitas mental yang paling dasar.
Terdapat enam kategori proses kognitif dalam taksonomi Bloom yang direvisi oleh Anderson dan Krathwohl, keenam proses kognitif ini kemudian diklasifikasikan menjadi 2 kelompok yaitu keterampilan berpikir tingkat rendah atau Lower Order Thinking Skills (LOTS) dan Higher Order Thinking Skills (HOTS). Tiga proses kognitif yang tergolong LOTS adalah mengingat, memahami, dan mengaplikasikan sedangkan yang termasuk HOTS adalah Menganalisis, Mengevaluasi, dan Mencipta (Anderson \& Krathwohl, 2010; Yoki, et al., 2018).

Guru percaya bahwa penerapan HOTS pada pembelajaran adalah hal yang penting (Retnawati, et al., 2018). Pengembangan pembelajaran berorientasi pada keterampilan berpikir tingkat tinggi atau Higher Order Thinking Skill (HOTS) merupakan upaya yang dilakukan untuk meningkatkan kualitas pembelajaran khususnya biologi dan lebih jauh dapat meningkatkan kualitas lulusan. Peningkatan kualitas lulusan dilakukan oleh guru dengan berfokus pada tingkat kesulitan materi tertentu dan peningkatan kualitas pembelajaran di kelas. Peningkatan kualitas ini ditempuh salah satunya dengan berorientasi pada HOTS.

Proses implementasi HOTS dalam pembelajaran dapat diintegrasikan pada berbagai aspek baik dalam pembelajaran, seperti perumusan tujuan pembelajaran dalam tahapan perencanaan (Yusuf, et al. 2019), penyusunan langkah-langkah dan pemilihan strategi pembelajaran (Yoga, 2018), penyediaan modul (Pramesti, et al., 2019; Supriyatin, et al., 2019), pemilihan teknik dan pelaksanaan asesmen (Kusuma, et al, 2017).

Proses implementasi HOTS pada proses pembelajaran senantiasa dilaksanakan oleh sekolah termasuk sekolah di Kota Baubau khususnya di SMAN 2 Baubau. Pembelajaran biologi di SMAN 2 Baubau berupaya untuk 
mengintegrasikan berbagai kompetensi yang disyaratkan oleh kurikulum sebagai kompetensi yang dikuasai oleh peserta didik. Salah satu kompetensi yang menjadi fokus guru biologi pada proses pembelajaran di SMAN 2 Baubau adalah integrasi HOTS pada pembelajaran.

Upaya penerapan HOTS pada proses pembelajaran di SMAN 2 Baubau di kelas melibatkan guru yang berperan dalam merencanakan, melaksanakan, mengevaluasi, dan menindaklanjuti proses pembelajaran serta melibatkan peserta didik sebagai subyek yang belajar pada pembelajaran biologi yang terintegrasi HOTS. Peran guru dan penguasaan peserta didik menjadi hal yang perlu dianalisis untuk menentukan keberhasilan penerapan HOTS pada pembelajaran biologi. Oleh karena itu, maka dilakukan analisis mengenai penerapan HOTS pada pembelajaran biologi di SMAN 2 Baubau.

\section{METODE}

Penelitian ini merupakan penelitian deskriptif kualitatif. Penelitian deskriptif kualitatif dipilih agar mampu mendeskripsikan perilaku orang, peristiwa, dan fakta-fakta yang ada di lapangan, dalam hal ini peran guru, peserta didik, kepala sekolah, dan semua warga sekolah dalam latar penelitian yang berkaitan dengan penerapan Higher-Order Thinking Skills (HOTS) pada pembelajaran biologi di SMAN 2 Baubau. Penelitian ini dilaksanakan pada tahun akademik 2018-2019 mulai bulan Juli 2018 sampai bulan Juni 2019. Penelitian ini dilaksanakan di SMAN 2 Baubau. Subjek pada penelitian ini adalah kepala sekolah, peserta didik, dan guru biologi di SMAN 2 Baubau. Sedangkan objek pada penelitian ini adalah penerapan Higher-Order Thinking (HOTS) pada pembelajaran biologi di SMAN 2 Baubau.
Data yang dikumpulkan dalam penelitian ini adalah hasil wawancara terhadap kepala sekolah, guru dan peserta didik, hasil observasi pembelajaran dan respon siswa terhadap penerapan HOTS pada pembelajaran biologi. Instrumen yang digunakan pada penelitian ini adalah pedoman wawancara, lembar observasi pembelajaran, angket respon siswa terhadap penerapan HOTS pada pembelajaran, pedoman analisis dokumen pembelajaran. Teknik pengumpulan data dilakukan di luar kelas (wawancara dan dokumentasi) maupun di dalam kelas (observasi) selama proses pembelajaran.

Prosedur atau tahapan-tahapan yang dilaksanakan pada penelitian ini terbagi menjadi tahap pendahuluan, tahap pengumpulan data, tahap deskripsi dan analisis data, dan tahap akhir: (1) Tahap Pendahuluan, pada tahap ini masalah kemudian diidentifikasi guna menetapkan tujuan penelitian. pemilihan objek penelitian yaitu penerapan HOTS pada pembelajaran biologi di SMAN 2 Baubau dilakukan pada tahap ini. Setelah masalah, tujuan dan objek penelitian telah ditetapkan, pada tahap ini kemudian ditetapkan langkahlangkah penelitian dan diikuti penyusunan instrumen-instrumen yang kemudian digunakan pada tahap pengumpulan data; (2) Tahap Pengumpulan Data, pada tahap ini data kemudian dikumpulkan menggunakan instrumen yang dibuat pada tahap pendahuluan. Pada tahapan ini dilakukan wawancara, observasi pembelajaran, dan analisis terhadap dokumen-dokumen perangkat pembelajaran guru; (3) tahap analisis dan deskripsi data, pada tahap ini data yang diperoleh kemudian dianalisis dan dideskripsikan untuk memperoleh gambaran mengenai penerapan HOTS pada pembelajaran biologi di SMAN 2 
Baubau; (4) tahap akhir, pada tahap ini ditarik kesimpulan penelitian berdasarkan hasil analisis dan deskripsi data

Data yang diperoleh kemudian akan dianalisis menggunakan analisis kualitatif dengan mengacu pada (Miles, et al., 2014), yang terdiri atas tahapan: (1) Pengumpulan Data; (2) Reduksi Data; (3) Penyajian Data; dan (4) Penarikan kesimpulan. Temuantemuan hasil penelitian kemudian akan dideskripsikan sehingga memberikan gambaran yang detail mengenai penerapan Higher-Order Thinking Skills (HOTS) pada pembelajaran biologi di SMAN 2 Baubau

\section{PEMBAHASAN}

Penerapan HOTS pada pembelajaran biologi di SMAN 2 Baubau dilaksanakan melalui proses pembelajaran intrakurikuler. Penerapan tersebut dicapai melalui kolaborasi yang dilakukan antara guru biologi SMAN 2 Baubau, antara guru biologi SMAN di Kota Baubau dan antara guru biologi dengan dosen-dosen dari program studi pendidikan biologi Universitas Muhammadiyah Buton. Kolaborasi tersebut salah satunya dilaksanakan melalui penerapan Musayawarah Guru Mata Pelajaran atau MGMP (Irhamni, et al., 2017)

\section{Penerapan HOTS Melalui Proses Pembelajaran}

Penerapan HOTS pada proses pembelajaran biologi di SMAN 2 Baubau dilakukan dengan berbagai skenario atau metode pembelajaran. suatu metode pembelajaran tertentu dapat ditujukan untuk mengintegrasikan salah satu jenis dari HOTS dan metode pembelajaran yang lainnya dapat difokuskan untuk mengintegrasikan jenis HOTS yang berbeda pula, hal ini didasarkan pada hasil analisis terhadap materi pembelajaran, karakteristik peserta didik dan kesiapan sarana-dan prasarana pendukung bagi integrasi tersebut. Penerapan HOTS pada proses pembelajaran di SMAN 2 Baubau dilakukan pada tahap-tahap pembelajaran yakni tahap perencanaan, tahap pelaksanaan dan evaluasi, serta tahap tindak lanjut hasil pembelajaran.

\section{a. Tahap Perencanaan}

$\begin{array}{lr}\text { Tahap perencanaan } & \begin{array}{r}\text { dimulai } \\ \text { tujuan } \\ \text { dengan penyusunan } \\ \text { pembelajaran }\end{array} \\ \text { mempertimbangkan jenis } & \text { materi }\end{array}$ pembelajaran pada Kompetensi Dasar dan memilih skenario atau metode pembelajaran yang akan dilakukan termasuk jenis HOTS yang akan diintegrasikan dalam proses pembelajaran biologi di SMAN 2 Baubau.

Produk dari proses perencanaan oleh guru biologi di SMAN 2 Baubau dengan berkolaborasi dengan guru serta dosen dari perguruan tinggi berupa Rencana Pelaksanaan Pembelajaran dan Instrumen Pembelajaran lainnya seperti Lembar Kerja Peserta Didik, Lembar Soal tes, Lembar Kerja Praktikum, dan Rubrik Penilaian Hasil tes bergantung dari metode yang dipilih pada setiap materi pelajaran biologi.

Pemilihan metode pembelajaran dan jenis HOTS yang yang diintegrasikan berdasarkan materi biologi tertera pada Tabel 1, 2, dan 3 . Tabel 1 merupakan integrasi pada kelas $X$, tabel 2 merupakan integrasi pada kelas XI dan tabel 3 merupakan integrasi pada kelas XII.

Tabel 1. Penerapan HOTS pada

Pembelajaran Biologi Kelas X di SMAN 2 Baubau (Font 11)

No. Materi Biologi
$\begin{gathered}\text { Skenario } \\ \text { Pembelajaran }\end{gathered}$ $\begin{gathered}\text { HOTS yang } \\ \text { diintegrasikan }\end{gathered}$




\begin{tabular}{|c|c|c|c|}
\hline 1. & $\begin{array}{l}\text { Ruang Lingkup } \\
\text { Biologi }\end{array}$ & Peta Pikiran & Menganalisis \\
\hline 2. & $\begin{array}{l}\text { Keanekaragam } \\
\text { an Hayati }\end{array}$ & Peta Pikiran & Menganalisis \\
\hline 3. & $\begin{array}{l}\text { Klasifikasi } \\
\text { Lima Kingdom }\end{array}$ & Peta Pikiran & Menganalisis \\
\hline 4. & Virus & Kartu Flash & Mencipta \\
\hline 5. & Bakteri & Kartu Flash & Mencipta \\
\hline 6. & Protista & Kartu Flash & Mencipta \\
\hline 7. & Jamur & Kartu Flash & Mencipta \\
\hline 8. & Plantae & Kartu Flash & Mencipta \\
\hline 9. & Animalia & Kartu Flash & Mencipta \\
\hline 10. & Ekosistem & $\begin{array}{l}\text { Praktikum } \\
\text { Lapangan }\end{array}$ & $\begin{array}{l}\text { Mengevalu } \\
\text { asi }\end{array}$ \\
\hline 71 & $\begin{array}{l}\text { Perubahan } \\
\text { Lingkungan }\end{array}$ & $\begin{array}{c}\text { Proyek } \\
\text { Lingkungan }\end{array}$ & Mencipta \\
\hline
\end{tabular}

Sumber: diolah dari hasil penelitian

Tabel 1. Berisi ringkasan metode belajar yang dipilih oleh guru biologi SMAN 2 Baubau untuk mengintegrasikan HOTS dalam pembelajaran biologi. terdapat 11 jenis materi pelajaran biologi yang kemudian dilaksanakan dengan empat metode pembelajaran dalam pelaksanaannya.

Empat jenis metode tersebut adalah metode peta pikiran, kartu flash, praktikum lapangan, dan proyek lingkungan. Pemilihan peta pikiran pada materi ruang lingkup biologi, keanekaragaman hayati dan klasifikasi lima kingdom didasarkan pada karakteristik materi tersebut dimana siswa akan belajar konsep-konsep yang saling memiliki keterkaitan, memilah mana yang merupakan contoh dan bukan contoh dari setiap konsep dan pada proses pembelajarannya mereka kemudian diminta untuk menganalisis contoh-contoh dan membuat sebuah peta yang menunjukkan hubungan antar konsep tersebut.

Fatmawati (2016) menyatakan bahwa strategi mind mapping merupakan tools yang dapat digunakan oleh guru biologi untuk meningkatkan efektifitas pembelajaran biologi mereka. Lebih jauh, Elita (2018) melaporkan bahwa terjadi peningkatan hasil belajar biologi setelah belajar melalui penerapan mind map. Berdasarkan hal tersebut maka guru di SMAN 2 Baubau memutuskan untuk menggunakan metode peta pikiran untuk materi ruang lingkup biologi, keanekaragaman hayati, dan klasifikasi lima kingdom.

Pemilihan Kartu Flash sebagai skenario atau metode yang digunakan dalam pembelajaran biologi dengan materi virus, bakteri, protista, jamur, plantae, dan animalia dikarenakan pada aktivitas ini siswa diharapkan akan mempelajari secara mendalam dan lebih detail dalam mengelompokkan makhluk hidup dalam kelompok tertentu melalui aktivitas mencipta dalam bentuk pembuatan kartu flash.

Kartu flash memiliki keunggulan dalam hal membantu peserta didik menguasai kosa kata (Atmaja \& Sonia, 2020). Penggunaan kartu flash menjadi sesuai karena karakteristik dari materimateri yang dipilih sangat erat dengan penggunaan istilah dan bahasa latin. Sedangkan Grillo (2011) menyatakan bahwa kartu Flash dapat digunakan untuk meningkatkan penguasaan vocabulary biologi.

Pemilihan praktikum lapangan sebagai metode untuk materi ekosistem didasarkan pada kondisi geografis SMAN 2 Baubau yang terletak pada wilayah geografis yang berdekatan dengan pantai dan pegunungan khususnya hutan Lambusango yang terkenal sebagai paru-paru dunia. Praktikum lapangan dimaksudkan untuk mengajak siswa untuk belajar pada laboratorium alamiah yang merupakan kekayaan yang dimiliki oleh negara Indonesia khususnya pulau buton sebagai wilayah geografis dimana SMAN 2 berada, melalui praktikum lapangan peserta didik diajak untuk mengambil contoh-contoh yang ada pada lokasi praktikum lapangan dalam menghadirkan contoh-contoh dan menganalisa ekosistem yang ditemui saat praktikum lapangan.

Salah satu pertimbangan guru dalam melaksanakan pembelajaran 
adalah bagaimana mengajarkan biologi dalam konteks "lapangan". Pembelajaran dengan setting pada habitat dan lingkungan alaminya merupakan upaya untuk menghadirkan pembelajaran dalam konteks yang nyata (Fleischner et al., 2017). Pembelajaran dengan menggunakan alam sebagai laboratorium sangat disukai oleh siswa karena mereka dapat langsung melihat contoh lingkungan alaminya.

Proses pembelajaran pada materi perubahan lingkungan ditempuh dengan metode proyek lingkungan. hal ini dilakukan agar menumbuhkan kesadaran kepada peserta didik bahwa mereka adalah bagian dari lingkungan yang perlu mengambil bagian dalam menjaga lingkungan agar tetap sehat. Proyek lingkungan ini meminta peserta didik untuk menyusun rencana dan melaksanakan upaya untuk menjaga lingkungan ataupun membuat alat dengan prinsip perbaikan kualitas lingkungan.

Penggunaan proyek dalam pembelajaran biologi membantu siswa untuk menghasilkan rancangan maupun hasil karya yang lebih jauh mampu meningkatkan hasil belajar siswa (Taharu et al., 2019). (Basche, et al., 2016) menyatakan bahwa pembelajaran berbasis proyek dapat meningkatkan pemahaman pada topik lingkungan. Berdasarkan hal tersebut maka pembelajaran berbasis proyek kemudian diterapkan pada pembelajaran biologi dengan topik perubahan lingkungan di SMAN 2 Baubau.

Tabel 2. Penerapan HOTS pada Pembelajaran Biologi Kelas XI di SMAN 2 Baubau No. Materi Biologi $\begin{gathered}\text { Skenario } \\ \text { Pembelajaran }\end{gathered} \begin{gathered}\text { HOTS yang } \\ \text { diintegrasikan }\end{gathered}$

Praktikum Menganalisis dan Peta

Pikiran

2. Jeringan Peta Pikiran Menganalisis Tumbuhan

3. Jaringan Peta Pikiran Menganalisis Hewan

4. Sistem Gerak Dokter Siswa Mengevaluasi Menjelaskan

5. Sistem Sirkulasi Dokter Siswa Mengevaluasi

6. Menjelaskan

7. Sistem Praktikum Menganalisis Pencernaan Bahan makanan

8. Sistem Dokter Siswa Mengevaluasi Respirasi Menjelaskan

9. Sistem Ekskresi Dokter Siswa Mengevaluasi

10. Sistem Dokter Siswa Mengevaluasi Koordinasi Menjelaskan

11. Senyawa Pembuatan Mencipta Psikotropika Video

Penyalahgun aan Narkoba

12. Sistem Dokter Siswa Mengevaluasi Reproduksi Menjelaskan

13. ASI Eksklusif Duta ASI Mengevaluasi dan Keluarga eksklusif dan Berencana Keluarga Berencana

14. Sistem Imun Dokter Siswa Mengevaluasi Menjelaskan

Sumber: diolah dari data hasil penelitian

Metode pembelajaran yang spesifik dilaksanakan di kelas XI adalah praktikum dipadu peta pikiran, dokter siswa menjelaskan, dan duta asi eksklusif dan keluarga berencana. Tiga jenis metode pembelajaran ini dipilih karena karakteristik materi yang sesifik pada kelas XI.

Praktikum dipadu dengan peta pikiran dipilih karena pada materi ini peserta didik dilatih untuk melakukan praktikum dan mengembangkan keterampilan penggunaan mikroskop dalam mempelajari sel, selain itu juga peta pikiran ditujukan agar peserta didik dapat menganalisis konsep sel untuk kemudian membuat peta pikiran yang memuat hubungan antar setiap komponen sel tersebut dalam mendukung fungsinya. (Taharu, 2017) menyatakan bahwa penggunaan praktikum dapat meningkatkan hasil 
belajar siswa sedangkan menurut Septiani, et al. (2014) menyatakan bahwa peta pikiran mampu meningkatkan retensi pada pembelajaran biologi.

Metode pembelajaran biologi dengan menggunakan skenario dokter siswa menjawab ditujukan untuk menciptakan kondisi dimana peserta didik bertindak sebagai dokter yang menganalisis sebuah kondisi pada suatu pasien dan kemudian menjelaskan bagaimana mekanisme penyakit atau kelainan pada pasien tersebut dan bagaimana pencegahan dan pengobatannya. Pembelajaran ini dimaksudkan untuk memupuk semangat peserta didik khususnya yang bercita-cita sebagai dokter agar lebih giat dalam belajar. Sedangkan Metode pembelajaran dengan skenario peserta didik sebagai duta ASI dan Keluarga Berencana ditujukan agar peserta didik dapat mengembangkan kemampuannya dalam berkomunikasi dan menyampaikan informasi.

Tabel 3. Penerapan HOTS pada Pembelajaran Biologi Kelas XII di SMAN 2 Baubau

No. Materi Biologi $\begin{gathered}\text { Skenario } \\ \text { Pembelajaran }\end{gathered} \begin{gathered}\text { HOTS yang } \\ \text { diintegrasikan }\end{gathered}$

1. Pertumbuhan Praktikum Menganalisis dan

Perkembangan

Makhluk

Hidup

2. Metabolisme Peta Pikiran

3. Substansi Penyusunan Genetik Artikel

4. Pembelahan Sel Peta Pikiran

5. Pola-Pola Tutor Sebaya Pewarisan Sifat

6. Pautan dan Tutor Sebaya Mengevaluasi Pindah Silang

7. Mutasi Penyusuna Artikel

8. Evolusi

Pembuatan

Time line

9. Bioteknologi
Menganalisis

Mencipta

Menganalisis

Mengevaluasi

Mencipta

Mencipta

Mencipta
Skenario yang khas pada metode pembelajaran di kelas XII adalah penyusunan artikel, tutor sebaya, dan pembuatan timeline. Penyusunan artikel dimaksudkan agar peserta didik terbiasa dalam menyusun artikel ilmiah, sedangkan tutor sebaya dimaksudkan agar rekan yang memiliki kemampuan akademik tinggi mampu membantu rekan sebayanya mengingat topik genetika merupakan topik yang membutuhkan pendampingan cukup tinggi. Penyusunan timeline dimaksudkan agar peserta didik dapat menyusun sejarah evolusi dalam suatu urutan yang tertera pada timeline.

\section{b. Tahap Pelaksanaan dan Evaluasi}

Tahap pelaksanaan merupakan tahapan dimana perencanaan pembelajaran yang telah diterapkan oleh guru biologi di SMAN 2 Baubau dalam mengintegrasikan HOTS kemudian dilaksanakan dalam proses pembelajaran. Setelah dilaksanakan proses pembelajaran, guru dan peserta didik kemudian memiliki respon yang beragam dalam mengikuti scenario belajar yang telah ditetapkan.

Guru menemukan bahwa pada skenario peta pikiran siswa cenderung memiliki kesulitan dalam menentukan hubungan antara konsep dan membutuhkan pendampingan yang lebih intensif, sedangkan pada pembuatan kartu flash, ukuran kartu yang terlalu kecil menjadikan peserta didik membutuhkan banyak kartu untuk menyelesaikan proses pembuatan kartu flash tersebut.

Praktikum dan praktikum lapangan merupakan skenario yang paling disenangi oleh peserta didik, akan tetapi penuntun praktikum lapangan yang baik dan mudah dimengerti menjadi hal yang penting pada skenario ini.

Dokter siswa menjelaskan 
merupakan skenario dimana peserta didik terlihat untuk berkompetensi dan melakukan banyak wawancara khususnya dengan petugas medis seperti perawat dan dokter. Akan tetapi waktu dan control terhadap proses wawancara menjadi perhatian pada skenario ini.

Pembuatan video penyalahgunaan narkoba dan duta ASI dan Keluarga Berencana mampu mendorong literasi teknologi dan kerja kelompok antar peserta didik namun, seperti pada scenario dokter siswa menjelaskan, skenario ini juga memiliki tantangan pada manajemen waktu dan kontrol terhadap progress pekerjaan peserta didik.

Penyusunan artikel merupakan skenario pembelajaran yang dinilai paling sulit oleh peserta didik sehingga pada skenario ini guru memberikan bimbingan yang cukup besar. Sedangkan skenario tutor sebaya dinilai mampu memberikan bimbingan yang cukup besar kepada peserta didik yang mengalami kesulitan karena rekan sebaya dinilai mampu untuk membantu peserta didik yang kesulitan menyampaikan pada bagian mana topik pembelajaran yang tidak dipahaminya.

Skenario pembuatan timeline mendorong peserta didik untuk mengumpulkan referensi dan menyajikannya dengancara-cara yang kreatif sehingga diperoleh tugas yang bervariasi dengan desain-desain yang kreatif dari masing-masing kelompok. Sedangkan pada skenario proyek bioteknologi peserta didik belajar untuk membuat produk bioteknologi konvensional dengan tujuan untuk memberikan keterampilan life skill kepada peserta didik sehingga diharapkan para peserta didik dapat memandang ilmu biologi dalam konteks yang lebih luas yang juga mampu menanamkan life skill.

\section{c. Tahap Tindak Lanjut Hasil Pembelajaran}

Tahapan tidak lanjut merupakan tahapan dimana guru kemudian menyusun rencana pembelajaran yang akan dilaksanakan sebagai perbaikan dari proses pembelajaran yang telah dilaksanakan. Namun pada penelitian ini tahapan tindak lanjut hanya dibatasi pada pengumpulan ide untuk perbaikan pembelajaran berikutnya melalui kolaborasi antar guru biologi SMAN 2 Baubau, antara guru biologi di SMAN 2 Baubau maupun dengan dosen dari perguruan tinggi.

Tindak lanjut yang akan diterapkan selanjutnya adalah dengan melaksanakan Penelitian Tindakan Kelas kolaboratif untuk mengatasi setiap permasalahan yang ditemukan dalam setiap skenario proses integrasi HOTS pada pembelajaran biologi di SMAN 2 Baubau.

\section{PENUTUP}

Simpulan dari penelitian ini yaitu:

1. Penerapan HOTS pada pembelajaran biologi di SMAN 2 Baubau dilakukan melalu proses pembelajaran intrakurikuler dengan dilaksanakan pada tahap perencanaan, pelaksanaan dan evaluasi, serta tahap tindak lanjut hasil pembelajaran.

2. Penerapan HOTS dilaksanakan melalui scenario pembuatan peta pikiran, kartu flash, praktikum dan praktikum lapangan, proyek lingkungan dan bioteknologi, dokter siswa menjelaskan, pembuatan video penyalahgunaan narkoba, duta ASI dan Keluarga Berencana, Penyusunan artikel, Tutor Sebaya, dan Pembuatan Timeline.

\section{DAFTAR PUSTAKA}

Anderson, Lorin, W., \& Krathwohl, 
D. R. (2010). A Taxonomy for Learning, Teaching and Assessing: A Revision of Bloom's Taxonomy of Educational Objectives Terjamahan: Kerangka Landasan untuk Pembelajaran, Pengajaran, dan Asesmen. (A. Prihantoro, Ed.). Pustaka Pelajar.

Atmaja, A. S. K., \& Sonia, G. (2020). USING FLASH CARDS TO IMPROVE STUDENTS' VOCABULARY. PROJECT (Professional Journal of English Education).

https:// doi.org/10.22460/proje ct.v3i2.p283-289

Basche, A., Genareo, V., Leshem, A., Kissell, A., \& Pauley, J. (2016). Engaging Middle School Students through Locally Focused Environmental Science Project-Based Learning. Natural Sciences Education. https:// doi.org/10.4195/nse201 6.05.0012

Cimer, A. (2012). What makes biology learning difficult and effective: Students' views.Educational Research and Reviews,. Students' Views.Educational Research and Reviews.

Elita, U. (2018). Peningkatan Hasil Belajar Menggunakan Metode Pembelajaran Mind Mapping. BIOEDUSAINS Jurnal Pendidikan Biologi Dan Sains, 1(2), 177-182. https:/ / doi.org/https:/ / doi.or g/10.31539/bioedusains.v1i2.37 2

Fatmawati, B. (2016). The analysis of students' creative thinking ability using mind map in biotechnology course. Jurnal Pendidikan IPA Indonesia. https://doi.org/10.15294/jpii.v $5 i 2.5825$

Fleischner, T. L., Espinoza, R. E., Gerrish, G. A., Greene, H. W., Kimmerer, R. W., Lacey, E. A., ... Zander, L. (2017). Teaching Biology in the Field: Importance, Challenges, and Solutions. BioScience. https:/ / doi.org/10.1093/biosci /bix036

Grillo, K. J. (2011). An Investigation of The Effects of Using Digital Flashcards to Increase Biology Vocabulary Knowledge in High School Students With Learning Disabilities. University of Central Florida. Retrieved from http:/ / etd.fcla.edu/CF /CFE000 3972/Grillo_Kelly_J_201108_Ph D.pdf

Irhamni, E., Murniati;, \& Niswanto. (2017). PENGELOLAAN MUSYAWARAH GURU MATA PELAJARAN BIOLOGI DALAM MENINGKATKAN KOMPETENSI PROFESIONAL GURU DI KOTA BANDA ACEH. Jurnal Administrasi Pendidikan : Program Pascasarjana Unsyiah, 6(3), 140146.

Kusuma, M. D., Rosidin, U., Abdurrahman, A., \& Suyatna, A. (2017). The Development of Higher Order Thinking Skill (Hots) Instrument Assessment In Physics Study. IOSR Journal of Research \& Method in Education (IOSRJRME). https://doi.org/10.9790/73880701052632

Miles, M. B., Michael Huberman, A., \& Saldaña, J. (2014). Qualitative data analysis: A methods Sourcebook (3rd Edition). SAGE 
Publications,

Inc.

https:// doi.org/10.1177/23970 0221402800402

Pramesti, B. N., Sajidan, S., Dwiastuti, S., \& Setyaningsih, E. (2019). The feasibility of biology module based on Stim-HOTS models. Jurnal Pendidikan Biologi Indonesia.

https://doi.org/10.22219/jpbi. v5i1.7385

Retnawati, H., Djidu, H., Kartianom, Apino, E., \& Anazifa, R. D. (2018). Teachers' knowledge about higher-order thinking skills and its learning strategy. Problems of Education in the 21st Century.

Supriyatin, Rahayu, S., Ristanto, R. H., \& Ichsan, I. Z. (2019). Improving hots in biology learning: A supplement book of plant growth and development. Universal Journal of Educational Research.

https:/ / doi.org/10.13189/ujer.2 019.071211

Taharu, F. I. (2017). Pemanfaatan Media Narik Layang Nutrient Agar Ekstrak Daging Ikan Layang (Decapterus russelli) Pada Pembelajaran Biologi Berbasis Praktikum Materi Bakteri. JURNAL BIOEDUCATION. https:// doi.org/10.29406/622

Taharu, F. I., Aba, L., Iksan, M., Kusrini, Nurwahida, Gazalin, J., ... Ibrahim, T. (2019). Projectbased learning to improve the conceptual knowledge of students in environmental microbiology topics. In IOP Conference Series: Earth and Environmental Science (Vol. 343). https://doi.org/10.1088/1755-
1315/343/1/012120

Yoga, D. (2018). Strategi Mengajar untuk Meningkatkan HOTS. Retrieved from http://lpmpjogja.kemdikbud.g o.id/strategi-mengajar-untukmeningkatkan-hots/

Yoki, A., Pudjiastuti, A., Bestary, R., \& Zamroni. (2018). Buku Pegangan Pembelajaran Berorientasi pada Keterampilan Berpikir Tingkat Tinggi. Direktorat Jenderal Guru dan Tenaga Kependidikan. Kementerian Pendidikan dan Kebudayaan. Jakarta.

Yusuf; Sadia, I Wayan; Suastra, I. W. S. (2019). Higher-order thinking skills (HOTS) in teaching and learning biology at Madrasah Aliyah. In Journal of Physics: Conference Series (pp. 1-6). IOP Publishing.

Yusup, I. R. (2018). Kesulitan Guru pada Pembelajaran Biologi Tingkat Madrasah/Sekolah di Provinsi Jawa Barat (Studi Kasus Wilayah Priangan Timur). BioEdUIN, 8(2), 34-42. 